\title{
Carbon and nitrogen stocks of a Typic Acrudox under different land use systems in São Paulo State of Brazil
}

\author{
Valdinei Tadeu Paulino ${ }^{1}$, Marcos Siqueira Neto ${ }^{2}$, Erika Maria Lima Celegato Teixeira ${ }^{1}$, \\ Keila Maria Roncato Duarte ${ }^{1}$, Alan Joseph Franzluebbers ${ }^{3}$ \\ ${ }^{1}$ Institute of Animal Science, Rua Heitor Penteado, 56. 13460-000, Centro, Nova Odessa, São Paulo State, Brazil \\ ${ }^{2}$ University of São Paulo, Center of Nuclear Energy in the Agriculture (CENA/USP). PO Box, 96, 13400-970, Piracicaba, São Paulo State, \\ Brazil \\ ${ }^{3}$ USDA - Agricultural Research Service - 3218 Williams Hall, Campus Box 7619, NCSU - Raleigh NC 27695-7619
}

Email address:

paulino@iz.sp.gov.br (V. T. Paulino), eritalia@hotmail.com (E. M. L. C. Teixeira), msiqueir@usp.br (M. S. Neto), alan.franzluebbers@ars.usda.gov (A. J. Franzluebbers)

\section{To cite this article:}

Valdinei Tadeu Paulino, Marcos Siqueira Neto, Erika Maria Lima Celegato Teixeira, Keila Maria Roncato Duarte, Alan Joseph Franzluebbers. Carbon and Nitrogen Stocks of a Typic Acrudox under Different Land Use Systems in São Paulo State of Brazil. Journal of Plant Sciences. Vol. 2, No. 5, 2014, pp. 192-200. doi: 10.11648/j.jps.20140205.17

\begin{abstract}
Soil organic matter affects physical, chemical and biological conditions, and has been used as a soil quality index to differentiate the effects of different land uses and management practices. The objective of this study was to evaluate soil stocks of $\mathrm{C}$ and $\mathrm{N}$ under different land uses (conventional-tillage cropping, integrated crop-livestock system, and permanent pasture). The study area was located at the Institute of Animal Science in the municipality of Nova Odessa, São Paulo State (Brazil), with soil classified as Typic Acrudox with medium texture. Land use systems were: (1) integrated crop-livestock with maize and Urochloa brizantha cv. Marandu; (2) integrated crop-livestock with maize and U. ruziziensis; (3) integrated crop-livestock with maize and $U$. brizantha cv. Piatã; (4) long-term (25-yr-old) pasture with $U$. brizantha; and (5) conventional-tillage cropping with- maize only. The results showed that (to the layer $0-40 \mathrm{~cm}$ depth) the integrated crop-livestock systems (ICLS) had greater soil organic C (52.4 $\mathrm{Mg} \mathrm{ha}^{-1}$ ) and $\mathrm{N}\left(4.3 \mathrm{Mg} \mathrm{ha}^{-1}\right)$ than cropping (46.5 $\mathrm{Mg} \mathrm{Cha}^{-1}$ and 4.0 Mg N ha ${ }^{-1}$ ) only or pasture only (47.6 $\mathrm{Mg} \mathrm{Cha}^{-1}$ and 3.9 $\left.\mathrm{Mg} \mathrm{N} \mathrm{ha}{ }^{-1}\right)$. The rotation with $U$. brizantha cv. Piatã had lower soil organic C $\left(48.5 \mathrm{Mg} \mathrm{ha}^{-1}\right)$ and $\mathrm{N}\left(3.9 \mathrm{Mg}\right.$ ha $\left.{ }^{-1}\right)$ than with $U$. brizantha cv. Marandu (56.2 $\mathrm{Mg} \mathrm{C}^{-1}$ and 4.5 $\mathrm{Mg} \mathrm{N}^{-1}$ ) and U. ruziziensis (56.6 Mg C ha ${ }^{-1}$ and 4.6 Mg N ha ${ }^{-1}$ ). These results suggest that integrated crop-livestock systems can be used to improve soil organic matter, and may have additional benefits in sustaining agricultural production in areas experiencing degradation from continuously grazed pastures.
\end{abstract}

Keywords: Conventional Tillage, Integrated Crop-Livestock System, Urochloa brizantha, Urochloa ruziziensis

\section{Introduction}

Soil organic matter (SOM) is recognized as an important characteristic of sustainable agricultural systems in the tropics and temperate regions [1]. It is considered an integrated characteristic of physical, chemical and biological soil conditions [2] and has been used as a soil quality index in different land uses and management practices [3].

Carbon and nitrogen are the main constituents of SOM with stocks varying, depending on land use and management practices. Crop residues and animal manure additions often promote SOM accumulation while erosion and soil disturbance cause SOM decline [4].

Conventional farming systems with intensive soil tillage often result in a decrease in $\mathrm{C}$ and $\mathrm{N}$ stocks compared with conservation agricultural systems using reduced and no-tillage $[5,6]$. In tropical regions, SOM mineralization is accelerated due to high temperature; in top soils, $>50 \%$ reduction in $\mathrm{C}$ stock has occurred with $\sim 10$ years of cultivation [7].

Pasture degradation has occurred in the tropics due to continuous grazing of large areas without sufficient regard to forage management [8]. Environmental, social, and financial imbalances have occurred, requiring producers to become more efficient. A system of intercropping grain crops with forages can provide enough forage in the dry season to maintain nutritional quality of livestock and even promote 
weight gain $[9,10]$. Such a system can cover soil in winter and spring to control erosion and provide sufficient residue for effective conservation-tillage cropping of grain crops [11]. Therefore, an integrated crop-livestock system (ICLS) that includes a crop phase and a pasture phase in rotation has strong potential for sustainable beef and grain crop production $[12,13]$.

Use of no-tillage mulching in an ICLS has shown improvements in soil aggregation and aggregate stability [14, 15], water infiltration [16], and efficacious erosion control [17]. As well, soil organic C can accumulate due to crop residues deposited on the soil surface and deep and dense root system development of forages [18].

Perennial pastures can contribute to soil $\mathrm{C}$ sequestration [19]. Several studies have shown significant soil organic C accumulation with well-managed grazing of pastures $[13,19$, $20,21,22]$. However, there are few studies that compare the efficiency of different grasses to maintain productivity and promote an increase in soil organic $\mathrm{C}$ concentration and stocks.

We hypothesized that an ICLS with maize cultivated under no-tillage in rotation with grazed pasture would result in accumulation of soil organic $\mathrm{C}$ and $\mathrm{N}$ compared with continuously grazed, degraded pasture or with conventionally tilled monoculture production of maize.

Our objective was to evaluate the stocks of soil organic $\mathrm{C}$ and $\mathrm{N}$ under alternative land uses from the prevailing degraded pasture condition in São Paulo State of Brazil.

\section{Material and Methods}

\subsection{Description of Study Area}

The study was located at the Institute of Animal Science ( $\left.22^{\circ} 46^{\prime} 28.8^{\prime \prime} \mathrm{S}, 47^{\circ} 17^{\prime} 38,2^{\prime \prime} \mathrm{W}\right)$ in the municipality of Nova Odessa, São Paulo State (Brazil) owned by Agencia Paulista de Tecnologia do Agronegocio (APTA), an organization supported by the Secretary of Agriculture and Supply in the State of São Paulo. The climate is mesothermal humid (Köppen - Cwa) with a subtropical wet winter of rain mainly from October to April and a dry season from May to September (Figure 1).

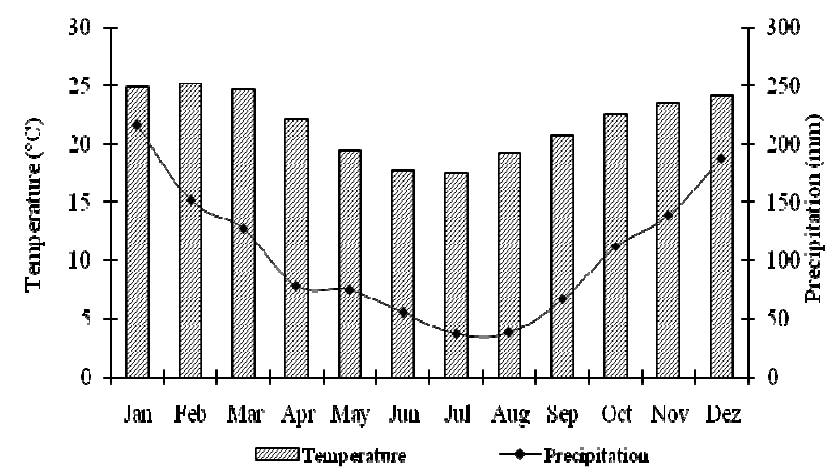

Figure 1. Long-term monthly means of temperature (bars) and precipitation (line + symbol) at the Institute of Animal Science in the municipality of Nova Odessa (São Paulo State, Brazil).
Long-term mean annual precipitation is $1280 \mathrm{~mm} \mathrm{yr}^{-1}$ and annual temperature is $21.7^{\circ} \mathrm{C}$. Soil was classified as a Typic Acrudox [23], composed of 55\% sand, 16\% silt, and 29\% clay. Native vegetation of the area was woodland Atlantic Forest biome.

A continuously grazed pasture area cultivated with Urochloa brizantha cv. Marandu was selected as the base condition for this study. The pasture had low productivity and high degradation from the original condition [24]. In August 2003 initial management upon conversion of a portion of the land area to ICLS consisted of surface application of $1.2 \mathrm{Mg}$ $\mathrm{ha}^{-1}$ of lime. In November 2004, the first planting of maize (Zea mays L.) was made with no-tillage in a mulch of grassy residues, using a chisel plow with cutting discs and winged tips. Maize was fertilized with $350 \mathrm{~kg} \mathrm{ha}^{-1}$ of 8-26-16 (NPK) applied in the groove at planting and $360 \mathrm{~kg} \mathrm{ha}^{-1}$ of 5-20-20 (NPK) as top dressing with mechanical incorporation to the soil using with a trencher at $5 \mathrm{~cm}$ depth. The top-dressing fertilizer was mixed with $10 \mathrm{~kg} \mathrm{ha}^{-1}$ grass seed with viability of $60 \%$.

\subsection{Treatments and Experimental Design}

Three grasses were tested: (i) U. brizantha (Hochst. ex A. Rich.) Webster cv. Marandu (ICLS-Ub-Mar), (ii) U. brizantha cv. Piatã (ICLS-Ub-Pia), and (iii) U. ruziziensis Germain \& Evrard (ICLS-Ur). The 2.5 ha of original pasture area was divided into three portions of $\sim 0.8$ ha each to test these systems.

This study was for seven years with the same annual cycle repeated. In March 2009, maize was harvested and produced 14.2 $\mathrm{Mg} \mathrm{ha}^{-1}$ of dry matter. At harvest, undersown grass pasture was already established and available for animal grazing until the next rainy season of maize planting. Animal grazing (from March to November 2009) was with average stocking rate of $540 \mathrm{~kg} \mathrm{ha}^{-1}$ live weight.

As reference, two areas were considered: (i) grazed pasture throughout the year, located immediately adjacent to the ICLS evaluation, which was cultivated for 25 years with U. brizantha cv. Marandu by applying $50 \mathrm{~kg} \mathrm{~N} \mathrm{ha}^{-1}$ (maintained as a reserve for the ICLS evaluation, such that animals grazed only periodically), with the stocking rate (3.44 animal unit ha-1, animal unit $=450 \mathrm{~kg}$ live weight), leading to a weight gain (863 kg ha ${ }^{-1}$, at $25 \mathrm{~cm}$ of pregrazing height) (long-term pasture; LT-Pasture) and, (ii) maize cut for silage by cultivating for 15 years with conventional tillage during the rainy season and fallow (spontaneous vegetation) during the dry season (CT-Maize). This reference area was $\sim 50 \mathrm{~m}$ from the area in ICLS evaluation.

The dry matter productivity of grasses evaluated in dry matter for the year 2009 in areas with ICLS were 9.0; 8.9 and $7.9 \mathrm{Mg} \mathrm{ha}^{-1} \mathrm{yr}^{-1}$, respectively for $U$. ruziziensis; U. brizantha var. Marandu and U. brizantha var. Piatã. Dry matter in the reference areas were $5.5 \mathrm{Mg} \mathrm{ha}^{-1} \mathrm{yr}^{-1}$ for LT_Pasture and 7.2 $\mathrm{Mg} \mathrm{ha}^{-1}$ for CT-Maize.

Thus, the evaluation was from three manipulative situations (ICLS with different grasses) and two references situations, 
here called references (LT-Pasture and CT-Maize), which were unreplicated, but areas distributed in space. We assumed that the soil and environmental conditions were uniform in the sampled areas, and therefore chose to sample pseudo-replications from the large experimental units [25]. Three pseudo-replications were sampled within each $\sim 0.8$ ha of treatment area.

\subsection{Soil Analysis}

Soil in the experiment was sampled seven years after treatment initiation, in September 2010 at depths of 0-10, 1020, 20-30 and 30-40 cm. Soil cores soil (five per pseudoreplication) were collected using a stainless steel cylinder $\left(100 \mathrm{~cm}^{3}\right)$ and diameter of $5 \mathrm{~cm}$. Soil was air-dried and sieved through $2 \mathrm{~mm}$ ). A portion of the sample was ground and sieved through 60 mesh sieves $(0.250 \mathrm{~mm})$ and sent to the Environmental Biogeochemistry laboratory (CENA-USP) to determine the total $\mathrm{C}$ and $\mathrm{N}$ concentration. The other samples were analyzed in the Department of Soils (ESALQ-USP). Chemical soil characterizations are shown in Table 1. Soil dry weight and water content were measured in the laboratory and soil bulk density was calculated [26]. Soil texture was determined with a hydrometer after dispersing with hexametaphosphate and digesting organic matter using $\mathrm{H}_{2} \mathrm{O}_{2}$. Soil $\mathrm{pH}$ was determined in $\mathrm{KCl}\left(1 \mathrm{~mol} \mathrm{~L}^{-1}\right)$ using a 1:2.5 soil:solution ratio. Cation exchange capacity at $\mathrm{pH} 7.0$, percent base saturation, and aluminum saturation were calculated by determining exchangeable cations, potential soil acidity, and aluminum, respectively.

Table 1. Soil chemical characteristics (0-20 and 20-40 cm) under different land use and management practices at the Institute of Animal Science in the municipality of Nova Odessa (Sao Paulo State, Brazil).

\begin{tabular}{|c|c|c|c|c|c|c|}
\hline \multirow{2}{*}{ Sites } & Depth & pH KCl & avail-P1 & CEC2 & BS3 & Al4 \\
\hline & \multicolumn{2}{|l|}{$\mathbf{c m}$} & mg kg-1 & mmolc dm dm $^{-3}$ & \multicolumn{2}{|l|}{$-\%-$} \\
\hline \multirow[t]{2}{*}{ LT-Pasture } & $0-20$ & 4.0 & 3.0 & 94.2 & 3.9 & 74.4 \\
\hline & $20-40$ & 4.0 & 2.1 & 78.8 & 3.6 & 79.3 \\
\hline \multirow[t]{2}{*}{ CT-Maize } & $0-20$ & 5.1 & 12.1 & 58.0 & 38.4 & 11.9 \\
\hline & $20-40$ & 4.2 & 6.6 & 44.6 & 20.4 & 33.1 \\
\hline \multirow[t]{2}{*}{ ICLS } & $0-20$ & 5.0 & 13.3 & 63.8 & 38.6 & 6.8 \\
\hline & $20-40$ & 4.6 & 8.1 & 51.2 & 25.8 & 26.0 \\
\hline
\end{tabular}

1 avail-P = available phosphorus; $2 \mathrm{CEC}=$ cation exchange capacity; $3 \mathrm{BS}=$ base saturation; $4 \mathrm{Al}=$ aluminum saturation.

Total $\mathrm{C}$ and $\mathrm{N}$ concentrations were determined by dry combustion using a LECO CN-2000 elemental analyzer. Soil $\mathrm{C}$ and $\mathrm{N}$ stocks were calculated from $\mathrm{C}$ and $\mathrm{N}$ concentrations and bulk density (Equation 1) [27].

$$
\mathrm{S}=\delta . h . T
$$

Where: $\mathrm{S}$ is the $\mathrm{C}$ or $\mathrm{N}$ stock in soil $\left(\mathrm{Mg} \mathrm{ha}^{-1}\right) ; \delta$ is the soil bulk density $\left(\mathrm{g} \mathrm{cm}^{-3}\right) ; \mathrm{h}$ is the soil sampled depth $(\mathrm{cm})$; and $\mathrm{T}$ is the total $\mathrm{C}$ or $\mathrm{N}$ concentration $\left(\mathrm{g} \mathrm{kg}^{-1}\right)$.

Since the samples were collected from fixed layers, calculation of inventory was adjusted to variations in soil bulk density following changes in management practices. Methodology described by [28, 29] was used to adjust $\mathrm{C}$ and $\mathrm{N}$ stocks to a soil mass equivalent (Equation 2 - from Sisti et al. [36]).

$$
\mathrm{Sc}=\Sigma \mathrm{n}-\mathrm{iS}+\{[\mathrm{Mai}-(\Sigma \mathrm{nMa}-\Sigma \mathrm{nMr})] . \mathrm{Ti}\}
$$

Where: $\mathrm{Sc}$ is the $\mathrm{C}$ or $\mathrm{N}$ stock corrected for soil mass $(\mathrm{Mg}$ ha-1), $\Sigma \mathrm{n}$-iS is the sum of stocks of layers without the deepest layer; Mai, is soil mass in the deepest layer; $\Sigma \mathrm{nMa}$ is the sum of soil masses sampled; $\Sigma \mathrm{nMr}$ is the sum of soil mass in the reference area, and $\mathrm{Ti}$ is the $\mathrm{C}$ or $\mathrm{N}$ concentration in the deepest layer sampled.

After correcting soil $\mathrm{C}$ and $\mathrm{N}$ stocks, we determined the estimated annual change in soil $\mathrm{C}$ and $\mathrm{N}$ storage (Equation 3):

$$
\Delta \mathrm{C}=(\mathrm{Ct}-\mathrm{Cr}) / \mathrm{t}
$$

Where: $\Delta \mathrm{C}$ is the change in soil $\mathrm{C}$ or $\mathrm{N}$ stock $\left(\mathrm{Mg} \mathrm{ha}^{-1} \mathrm{yr}^{-1}\right)$, $\mathrm{Ct}$ is the $\mathrm{C}$ or $\mathrm{N}$ stock in the treatment area $\left(\mathrm{Mg} \mathrm{ha}^{-1}\right), \mathrm{Cr}$ is the $\mathrm{C}$ or $\mathrm{N}$ stock in the reference area (baseline) $\left(\mathrm{Mg} \mathrm{ha}^{-1}\right)$, and $\mathrm{t}$ is time elapsed since the study was initiated (7 years).

\subsection{Statistical Analysis}

Analysis of variance (Kruskal-Wallis) was used to detect significant differences among treatments. Means were statistically separated using the Student Newman-Keuls test ( $\mathrm{p}$ $<0.05)$. Analyses were performed using SAS (2010).

\section{Results and Discussion}

Soil bulk density generally increased with depth due to overburden from the upper layers that promoted natural compression. Siqueira et al [30] also found greater soil bulk density in subsurface layers under different land uses in the Cerrado. This is a natural phenomenon in Oxisols of the region. Greater bulk density by soil compression reflects greater resistance to root penetration, water infiltration, and gas exchange [31]. 
Table 2. Soil bulk density $\left(\mathrm{Mg} \mathrm{m}^{-3}\right)$ under different land use and management practices under long-term pasture (LT-pasture), conventionally tilled maize silage (CT-maize), integrated crop-livestock systems with maize and Urochloa brizantha cv. Marandu (ICLS-Ub-Mar), with U. ruziziensis (ICLS-Ur), and with U. brizantha cv. Piatã (ICLS-Ub-Pia) at the Institute of Animal Science in the municipality of Nova Odessa (Sao Paulo State, Brazil).

\begin{tabular}{|c|c|c|c|c|c|}
\hline \multirow{2}{*}{ Depth } & LT-pasture & CT-maize & ICLS-Ub-Mar & ICLS-Ur & ICLS-Ub-Pia \\
\hline & \multicolumn{5}{|c|}{$\mathrm{Mg} \mathrm{m}^{-3}$} \\
\hline $0-10 \mathrm{~cm}$ & $1.26 \mathrm{c}$ & $1.42 \mathrm{~b}$ & $1.52 \mathrm{a}$ & $1.56 \mathrm{a}$ & $1.59 \mathrm{a}$ \\
\hline $10-20 \mathrm{~cm}$ & $1.29 \mathrm{c}$ & $1.57 \mathrm{a}$ & $1.49 \mathrm{~b}$ & $1.57 \mathrm{a}$ & $1.56 \mathrm{a}$ \\
\hline $20-30 \mathrm{~cm}$ & $1.29 \mathrm{c}$ & $1.51 \mathrm{~b}$ & $1.55 \mathrm{ab}$ & $1.56 \mathrm{a}$ & $1.59 \mathrm{a}$ \\
\hline $30-40 \mathrm{~cm}$ & $1.24 \mathrm{~d}$ & $1.45 \mathrm{c}$ & $1.56 \mathrm{~b}$ & $1.64 \mathrm{a}$ & $1.67 \mathrm{a}$ \\
\hline
\end{tabular}

Means $(n=3)$ followed by different letters in the same line differ significantly at $\mathrm{p}<0.05$.

At all soil depths, the lowest bulk density was in the reference area of long-term pasture (Table 2). At 0-10 cm, soil bulk density was greater under ICLS $\left(1.52-1.59 \mathrm{Mg} \mathrm{m}^{-3}\right)$ than under maize silage $\left(1.42 \mathrm{Mg} \mathrm{m}^{-3}\right)$ and long-term pasture $(1.26$ $\mathrm{Mg} \mathrm{m}-3)$. At lower depths, bulk density was generally equivalent between ICLS and maize silage $\left(1.45-1.67 \mathrm{Mg} \mathrm{m}^{-3}\right)$, both of which were greater than under long-term pasture (1.24-1.29 $\left.\mathrm{Mg} \mathrm{m}^{-3}\right)$. Long-term pasture had low animal trampling recently, due to being managed differently of late as a holding area for cattle grazing the ICLS treatments. Machinery traffic in ICLS and maize silage treatments may have contributed to compaction not experienced in long-term pasture. Inversion tillage operations in maize silage production would have alternately loosened soil immediately, but also led to some compaction with the exposure of uncovered soil surface to machinery traffic.

All treatments under ICLS had high soil bulk density, indicating some degree of soil compaction (Table 2). The values would have likely caused some limitations to root development and plant biomass production. Although surface soil under ICLS receives high levels of grass residues that can buffer against animal trampling effects on surface soil compaction [32], these results suggest that it may not have been enough to prevent compaction under ICLS in this study in soil composed of $55 \%$ sand, $16 \%$ silt, and $29 \%$ clay. Pasture land degradation occurs with low plant biomass production and nutrient stock depletion, both of which can lead to surface compaction due to animal trampling [33]. Under 3- to 20-yr-old pastures in an Oxisol from Rondônia State in northern Brazil, soil bulk density was lower than in this study (1.30-1.59 $\mathrm{Mg} \mathrm{m}^{-3}$ ) [29]. Soil bulk density between 1.1 and 1.5 $\mathrm{Mg} \mathrm{m}^{-3}$ are considered normal for soils with medium texture [34].

Some soil tillage disturbance was found to significantly increase maize biomass production at this location (Colet et al., [35]). This result may have been due to the degraded condition of soil derived from years of continuous overgrazing. According to [34], high soil bulk density between 1.27 and $1.57 \mathrm{Mg} \mathrm{m}^{-3}$ in sandy and clay soils, respectively, can be a limiting factor to root growth and water infiltration.

Soil $\mathrm{C}$ and $\mathrm{N}$ concentrations were greatest near the surface (Figure 2a, b). In the surface layer $(0-10 \mathrm{~cm}), \mathrm{C}$ concentration ranged between 14.9 and $16.8 \mathrm{~g} \mathrm{~kg}^{-1}$ for ICLS-Ub-Pia and ICLS-Ub-Mar, respectively; while $\mathrm{N}$ concentration ranged between 1.2 and $1.4 \mathrm{~g} \mathrm{~kg}^{-1}$ for CT-maize and ICLS-Ub-Mar, respectively. Soil $\mathrm{C}$ and $\mathrm{N}$ concentrations were typical, i.e. higher concentrations at the surface and lower concentrations with increasing depth. With depth, soil $\mathrm{C}$ and $\mathrm{N}$ concentrations became more similar among treatments due to the decreasing influence of surface deposition of organic matter inputs. Surface soil $\mathrm{C}$ accumulation can occur due to deposition of leaves, stems and roots. Greater SOM at the surface was also found under B. decumbens Stapf [49], similar to that observed by [21] under Panicum maximum Jacq, U. brizantha, and Paspalum atratum Swallen.
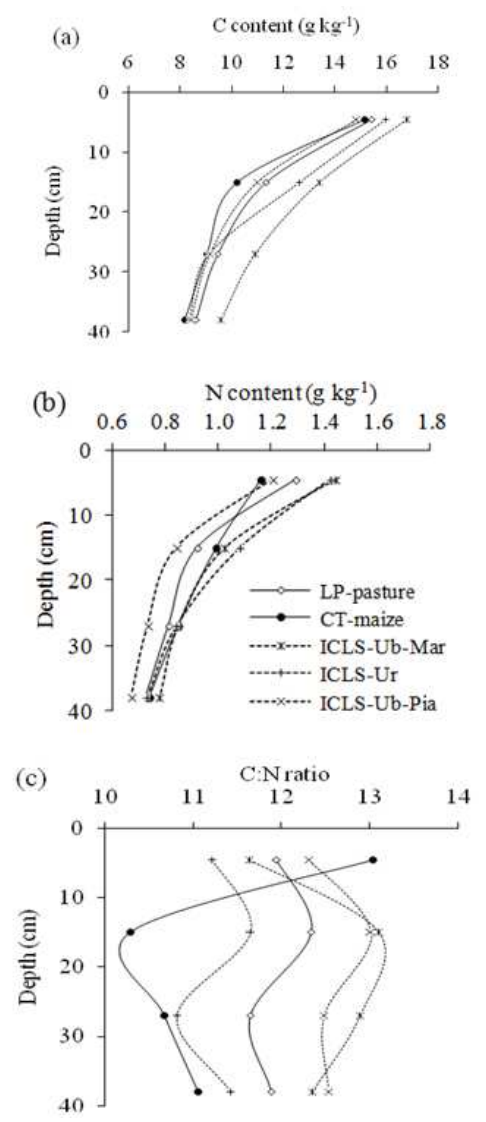

Figure 2. Carbon (a) and nitrogen (b) concentrations and $C: N$ ratio (c) in different depths under long-term pasture (LT-pasture), conventionally tilled maize silage (CT-maize), integrated crop-livestock systems with maize and Urochloa brizantha cv. Marandu (ICLS-Ub-Mar), with U. ruziziensis (ICLS-Ur), and with U. brizantha cv. Piatã (ICLS-Ub-Pia) at the Institute of Animal Science in the municipality of Nova Odessa (São Paulo state, Brazil). 
Several studies have shown that plant or crop residues maintained on the soil surface with reduced tillage systems promotes initially greater depth stratification of SOM content, represented by low $\mathrm{C}$ and $\mathrm{N}$ concentrations deeper into the soil profile $[4,30,36]$. The initial condition of soil physical and chemical limitations for cultivation resulted in low organic $\mathrm{C}$ contents. The amounts of $\mathrm{N}$ present in the soil were deficient and limited the addition of $\mathrm{C}$ in systems constituted mainly by grasses, and showed that the difference in soil $\mathrm{C}$ and $\mathrm{N}$ between ICLS and CT-maize was not so large in this soil. The $\mathrm{C}: \mathrm{N}$ ratio of SOM was similar among depths sampled and values were similar to those recognized for stable SOM in the tropics.

Most soil $\mathrm{N}$ is originally supplied by SOM, and the rates of this element range between 0.5 and $5 \mathrm{~g} \mathrm{~kg}^{-1}$ [37].In good managing pasture areas the organic matter amount (SOM) and total soil $\mathrm{N}$ were superior to those found in native vegetation areas [21]. Changes in N stocks are driven mainly by the quantity and type of residue deposited in the soil [36].

Kitchel et al. [38] showed that management of pasture with $\mathrm{N}$-fertilizer application (50 to $100 \mathrm{~kg} \mathrm{~N} \mathrm{ha}^{-1} \mathrm{yr}^{-1}$ ) provided increases in animal production but also in the following crops production in succession. In areas previously planted with fodder that received $\mathrm{N}$-fertilizer increased yields of maize (in the Mato Grosso do Sul State have been observed, indicating the importance of this technology for forage production in autumn-winter season, and improving in the crop residue and grain production. Maize yields were higher when established on the fertilized pasture. It is noteworthy that the dry mass of crop residue on the soil surface and dry mass of roots to $60 \mathrm{~cm}$ depth were: 7.200 and $7.800 \mathrm{~kg} \mathrm{ha} \mathrm{ha}^{-1}$, respectively, at unfertilized pasture, and 11.600 and $14.500 \mathrm{~kg} \mathrm{ha}^{-1}$, respectively, in the pasture that received $\mathrm{N}$-fertilizer, which provided better soil cover and resulted in greater nutrient cycling, favoring crops [39].

This gives a hint that the high $\mathrm{C}$ input from plant residues were being offset by additional $\mathrm{N}$ from somewhere in the system. Additional $\mathrm{N}$ could be due to fertilizer input in ICLS (although there is high $\mathrm{N}$ demand by maize that is subsequently exported in grain harvest), or due to biological $\mathrm{N}$ fixation by diazotrophic communities present in the rhizosphere of grasses or as endophytic mutualists [40].

Highest soil C stocks were obtained under ICLS-Ub-Mar and ICLS-Ur followed by ICLS-Ub-Pia, long-term pasture, and CT maize (Figure 3A).

Table 3. Soil C stocks $\left(M g \mathrm{ha}^{-1}\right)$ to different land use and soil management in the Brazil.

\begin{tabular}{|c|c|c|c|c|c|c|}
\hline \multirow{2}{*}{$\begin{array}{l}\text { Site } \\
\text { Municipality (Brazilian State) }\end{array}$} & \multirow[t]{2}{*}{ Soil classification $\nmid$} & \multicolumn{4}{|c|}{ Soil C stocks (time) } & \multirow[t]{2}{*}{ Reference } \\
\hline & & Pasture & $\mathrm{CT}$ & NT & ICLS & \\
\hline Campo Grande (MS) & Typic Hapludox & $53.5(30)$ & $46.3(11)$ & $47.4(11)$ & $50.5(11)$ & {$[13]$} \\
\hline Chupinguaia (RO) & Rhodic Kandiudox & $65.8(11)$ & & $49.2(2)$ & $61.4(5)$ & {$[48]$} \\
\hline Chupinguaia (RO) & Rhodic Kandiudox & $61.2(15)$ & & $53.4(2)$ & $50.1(1)$ & {$[48]$} \\
\hline Dourados (MS) & Typic Hapludox & $50.1(9)$ & $44.1(38)$ & $42.6(9)$ & $48.0(9)$ & {$[13]$} \\
\hline Itaubá (MT) & Typic Hapludox & $55.9(22)$ & & $46.0(17)$ & & {$[50,51]$} \\
\hline Itiquira (MT) & Typic Hapludox & $75.1(17)$ & $62.6(15)$ & $74.5(17)$ & & {$[50,51]$} \\
\hline Maracajú (MS) & Typic Hapludox & $65.8(33)$ & $51.7(11)$ & $56.6(11)$ & $61.4(11)$ & {$[13]$} \\
\hline Montividiu (GO) & Typic Hapludox & $75.4(21)$ & & $60.9(21)$ & $73.0(8)$ & {$[48]$} \\
\hline Morrinhos (MG) & Typic Hapludox & $40.7(5)$ & $34.1(5)$ & $40.2(5)$ & & [49] \\
\hline Planaltina (DF) & Typic Acrustox & $42.2(15)$ & $37.3(15)$ & $47.3(15)$ & & {$[52]$} \\
\hline Planaltina (DF) & Typic Acrustox & $52.9(13)$ & $53.3(13)$ & $56.0(13)$ & $52.2(13)$ & {$[53]$} \\
\hline Rio Verde (GO) & Typic Hapludox & $51.7(17)$ & $49.0(26)$ & $63.0(12)$ & & {$[54]$} \\
\hline Santa Carmen (MT) & Typic Hapludox & $54.3(13)$ & & $56.4(13)$ & $62.8(4)$ & {$[48]$} \\
\hline Santa Carmen (MT) & Typic Hapludox & $57.1(10)$ & & & $61.5(4)$ & [48] \\
\hline Sorriso (MT) & Typic Hapludox & $50.5(20)$ & $61.7(2)$ & $58.0(20)$ & & {$[50,51]$} \\
\hline Mean \pm S.D. $\dagger$ & & $56.8 \pm 11.0$ & $48.9 \pm 12.0$ & $53.7 \pm 9.4$ & $58.2 \pm 8.4$ & \\
\hline
\end{tabular}

$\dagger$ S.D. $=$ Standard deviation; $\$$ Soil Survey Staff (1999).

Similarly, soil N stock was greater in the ICLS-Ub-Mar and ICLS-Ur than other systems (Figure 3B). No differences occurred among ICLS-Ub-Pia and the two references areas.

Annual plowing and harrowing of maize led to organic matter mineralization and, consequently, lowest soil $\mathrm{C}$ stock. The continuous soil disturbance in CT areas followed by the low quantity of crop residues incorporated resulted in lower levels of soil $\mathrm{C}$ and $\mathrm{N}$. Moreover, the use of disk harrowing in soil preparation for planting in conventional tillage may be considered the most aggressive system for soils, with significant SOM losses [2].

Several studies (Table 3) have compared the soil $\mathrm{C}$-accumulation under different land use and management practices. The few studies with assessment of ICLS showed a tendency for greater soil C-sequestration.

Conservation tillage systems, as zero-tillage, no-tillage or minimal tillage, with minimum soil disturbance, crop rotation and mulching with crop residues also maintained a high level of SOM [26] and therefore improve soil quality [40]. The accumulation of SOM in no-tillage systems occurs slowly [2] so the comparisons between conventional and no-tillage systems do not usually show significant differences in the short term, owing to the high decomposition rates at high temperatures). 

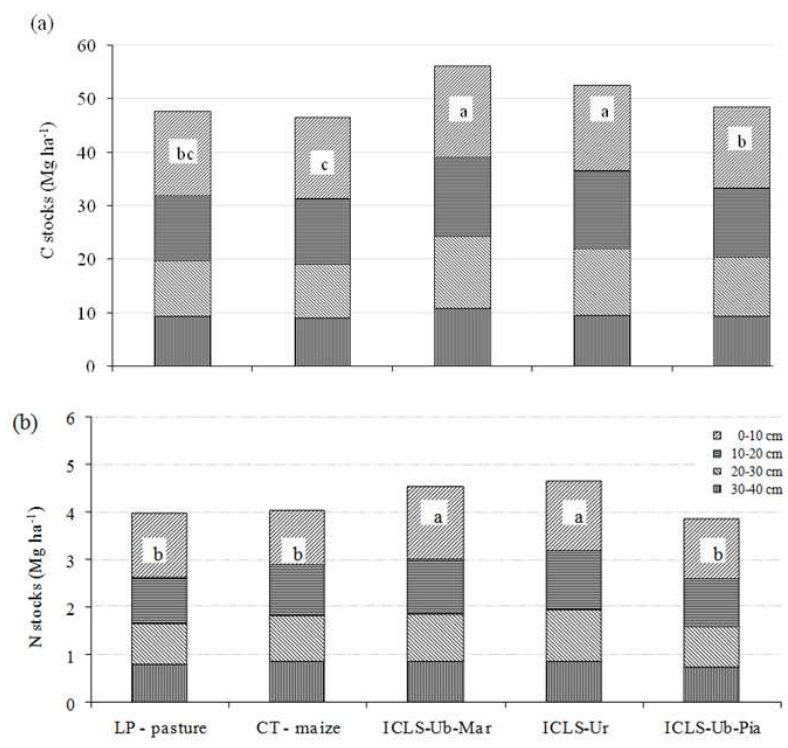

Figure 3. Soil $C$ (a) and $N$ (b) stocks in different depths under long-term pasture (LT-pasture), conventionally tilled maize silage (CT-maize), integrated crop-livestock systems with maize and Urochloa brizantha $\mathrm{cv}$. Marandu (ICLS-Ub-Mar), with U. ruziziensis (ICLS-Ur), and with U. brizantha cv. Piatã (ICLS-Ub-Pia) at the Institute of Animal Science in the municipality of Nova Odessa (São Paulo State, Brazil). Means $(n=3)$ with different letters at a depth $0-40 \mathrm{~cm}$ differ significantly at $p<0.05$.

Roesch et al. [41] attributed soil C accumulation under conservation tillage systems to two main factors: i) physical protection of organic compounds against microbial decomposition, favored by the $\mathrm{C}$ occlusion in soil aggregates; and ii) chemical protection of organic compounds through their interaction with minerals and cations hindering their decomposition.

Zinn et al. [42] showed that $\mathrm{C}$ levels increased with greater clay content, as the colloidal fraction of the soil was able to form organo-mineral complexes with SOM. The colloidal fraction forms organic-mineral complexes with SOM, and is the main factor responsible for stabilizing $\mathrm{C}$ in soil [43]. About 60 to $95 \%$ of SOM is bound to the mineral fraction of the soil (clay + silt) at all depths, regardless of the cultivation or crop rotation system. When inside aggregates, SOM remains protected and becomes more recalcitrant, forming dense organo-minerals complexes protected from decomposition agents [44], thus favoring SOM accumulation.

Productive pastures can maintain soil $\mathrm{C}$ stock. Fisher et al. [45] estimated that the soil $\mathrm{C}$ stock after nine years with $B$. humidicola (Rendle) Schweick, was $2.6 \mathrm{Mg} \mathrm{C} \mathrm{ha}^{-1}$ greater than native vegetation in Colombia. Silva et al. [21] found that degraded pastures diminished $\mathrm{C}$ soil. Well managed patures, have great ability to maintain and even increase the $\mathrm{C}$ content in the surface and subsurface layer with time [20 - 21].

Adoption of ICLS is a conservation management practice, that maintains the managed pasture benefits to SOM, but also adds income from cropping and winter grazing [46].

Using the reference areas (LT-Pasture and CT-Maize), we determined the impact of management practices on estimated soil $\mathrm{C}$ and $\mathrm{N}$ sequestration rates (Table 4).
Table 4. Estimated rate of soil organic $C$ and $N$ sequestrations $\left(M g h a^{-1} y r^{-1}\right)$ under different land use and management practices at the Institute of Animal Science in the municipality of Nova Odessa (São Paulo state, Brazil).

\begin{tabular}{lllcc}
\hline & \multicolumn{2}{c}{$\begin{array}{l}\text { Compared with } \\
\text { LT-pasture }\end{array}$} & \multicolumn{2}{c}{ Compared with CT-maize } \\
\cline { 2 - 5 } Treatment & $\mathbf{C}$ & $\mathbf{N}$ & $\mathbf{C}$ & $\mathbf{N}$ \\
\cline { 2 - 5 } & \multicolumn{4}{c}{$\mathbf{M g ~ h a}^{-1} \mathbf{~ r r}^{-1}$} \\
\hline Depth 0-20 cm & & -0.01 & \\
CT-maize & -0.07 & 0.01 & 0.07 \\
ICLS-Ub-Mar & 0.58 & 0.05 & 0.65 & 0.07 \\
ICLS-Ur & 0.37 & 0.05 & 0.44 & 0.01 \\
ICLS-Ub-Pia & 0.04 & -0.01 & 0.11 & \\
Depth 0-40 cm & & & & \\
CT-maize & -0.15 & 0.01 & & 0.07 \\
ICLS-Ub-Mar & 1.23 & 0.07 & 1.38 & 0.09 \\
ICLS-Ur & 0.71 & 0.08 & 0.86 & -0.03 \\
ICLS-Ub-Pia & 0.12 & -0.02 & 0.28 & \\
\hline
\end{tabular}

With LT-pasture as the reference, soil $\mathrm{C}$ accumulated with ICLS in both the surface layer $(0-20 \mathrm{~cm})$ and deeper $(0-40 \mathrm{~cm})$ due to ICLS conversion regardless of the grass used. CT-maize resulted in a loss of soil $\mathrm{C}$ stock. Soil C accumulation rates were within the range of 0.11 to $3.04 \mathrm{Mg}$ $\mathrm{ha}^{-1} \mathrm{yr}^{-1}$ as found previously [46]. Interesting to highlight was that soil $\mathrm{N}$ sequestration occurred in treatments with large soil $\mathrm{C}$ accumulation, but $\mathrm{N}$ was lost under ICLS-Ub-Pia, which was associated with low soil $\mathrm{C}$ sequestration.

In the case of LT-pasture and the ICLS treatments after the corn harvest, total biomass productions of grasses were consumed by constant cattle interventions. Animals grazed ICLS pasture throughout the winter period when the grass was at least $25-30 \mathrm{~cm}$ tall, with rotations between treatments. Thus the remaining amount of organic material (dead dry matter) contribution to the soil $\mathrm{C}$ and $\mathrm{N}$ accumulation was estimated at $21.4 \%$ of the amount produced per rated grass.

Considering CT-maize as the reference condition, soil $\mathrm{C}$ sequestration rates of ICLS treatments increased slightly, while soil $\mathrm{N}$ sequestration rates were similar in magnitude as with LT-pasture as reference (Table 4). Significant soil C and N sequestration occurred with ICLS in both $0-20 \mathrm{~cm}$ and $20-40 \mathrm{~cm}$ depths. This indicates the potential of ICLS compared with the monocultures of maize under conventional tillage and continuous pasture without fertilizer and lime inputs to sequester soil organic $\mathrm{C}$ and $\mathrm{N}$, a process favored by root and shoot biomass from Urochloa sp. deposited on and in soil. Besides being abundant and bulky, this biomass is continuously renewed.

Important to note is that the maize crop in ICLS treatments, was harvested for silage, meanning, that total above-ground biomass was exported at harvest. Thus, we estimated that maximum above ground biomass of crop residues did not exceed $5 \%$ of the total quantity produced. Thus, for soil $\mathrm{C}$ and $\mathrm{N}$ formation, root biomass was the major contributor. 


\section{Conclusions}

Integrated crop-livestock systems have a great potential to increase SOM, represented in this study in the form of $\mathrm{C}$ and $\mathrm{N}$ stock accumulation. It was the combination of crops and pastures that improved soil organic $\mathrm{C}$ and $\mathrm{N}$ accumulation compared with continuation of long-term continuously grazed pasture or monoculture cultivation of maize alone. We found larger accumulation rates of soil organic $\mathrm{C}$ and $\mathrm{N}$ with $U$. brizantha cv. Marandu and $U$. ruziziensis than with $U$. brizantha cv. Piatã and with the reference conditions of long-term pasture or conventional tillage cultivation of maize.

\section{Acknowledgements}

Dr. Carlos Cerri - Environmental Biogeochemistry laboratory (CENA/USP) for soil $\mathrm{C}$ and $\mathrm{N}$ analysis, and Dr. João Batista de Andrade for the experimental areas.

\section{References}

[1] Craswell, E. T., Lefroy, R. D. B., 2001. The role and function of organic matter in tropical regions. Nutrient Cycling in Agroecosystems, 61, 7-18.

[2] Mielniczuk, J., 2008. Matéria orgânica e a sustentabilidade dos sistemas agrícolas. In: Santos, G. A., Silva, L. S., Canellas, L. P., Camargo, F. A. O. (Eds). Fundamentos da matéria orgânica do solo - ecossistemas tropicais e subtropicais. 2.ed. Porto Alegre, Metrópole, p.1-5.

[3] Lal, R., 2011. Sequestering carbon in soils of agro-ecosystems. Food Policy, 36, 33-39.

[4] Souza, E. D., Andrade Costa, S. E. V. G, Anghinoni, I., Carvalho, P. C. F., Andrigueti, M., Cao, E., 2009. Estoques de carbono orgânico e de nitrogênio no solo em sistema de integração lavoura-pecuária em plantio direto, submetido a intensidades de pastejo. Revista Brasileira de Ciência do Solo, $33,1829-1836$.

[5] Angers, D. A., Eriksen-Hamel, N. S., 2008. Full inversion tillage and organic carbon distribution in soil profiles: a meta-analysis. Soil Science Society of American Journal, 72, 1370-1374.

[6] Luo, Z., Wang, E., Sun, O. J., 2010. Can no-tillage stimulate carbon sequestration in agricultural soil? A meta-analysis of paired experiments. Geoderma, 155, 211-223.

[7] Sanchez, P. A., Logan, T. J., 1992. Myths and science about the chemistry and fertility of soils in the tropics. In: Lal, R., Sanchez, P. A. (Ed.). Myths and science of soil of the tropics. Madison: SSSA/ASA, p. 35-46. (Special Publication, 29).

[8] Dias-Filho, M. B., 2007. Degradação de pastagens: processos, causas e estratégias de recuperação. 3 ed. Belém: Embrapa, Amazônia Oriental, 190 p.

[9] Castro Filho, C., Henklain, J. C., Vieira, M. J., Casão Jr, R., 1991. Tillage methods and soil and wate conservation in southern in Brazil. Soil Tillage Research, 20, 271-283.

[10] Assman, T. S., Ronzelli, P., Moraes, A., Assmann, A. L., Koehler, H. S., Sandini, I., 2003. Rendimento de milho em área de integração lavoua-pecuária sob o sistema plantio direto, em presença e ausência de trevo branco, pastejo e nitrogênio. Revista Brasileira de Ciência do Solo, 27, 675-683.

[11] Barducci, R. S., Costa, C., Crusciol, C. A. C., Borghi, E., Putarov, T. C., Sarti, L. M. N., 2009. Produção de Urochloa brizantha e Panicum maximum com milho e adubação nitrogenada. Archivos de Zootecnia, 58, 211-222.

[12] Kluthcousk, J., Cobucci, T., Aidar, H., Yokoyama, L.P., Oliveira, I. P. Costa, J. L. S., Silva, J. G., Vilela, L., Barcellos, A O., Magnabosco, C. U., 2000. Sistema Santa Fé - Tecnologia Embrapa: integração lavoura-pecuáriaq pelo consorcio de culturas anuais com forrageiras, em áreas de lavoura, no sistema direto e convencional. 28 p. (Circular Técnica, 38).

[13] Salton, J.C., Mielniczuk, J., Bayer, C., Fabrício, A.C., Macedo, M.C.M., Broch, D.L., 2011. Teor e dinâmica do carbono no solo em sistemas de integração lavoura-pecuária. Pesquisa Agropecuária Brasileira, 46, 1349-1356.

[14] Machado, P. L. O. A., Freitas, P. L., 2004. No-till farming in Brazil and its impact on food security and environmental quality. In: Lal, R., Hobbs, N. Uphoff, D. O., Hansen, R. (Eds.). Sustainable agriculture and the international rice-wheat system. Marcel Dekker: New York, pp. 291-310.

[15] Madari, B., Machado, P. L. O. A., Torres, E., Andrade, A. G., Valencia, L. I. O., 2005. No tillage and crop rotation effects on soil aggregation and organic carbon in a Rhodic Ferralsol from southern Brazil. Soil and Tillage Research, 80, 185-20.

[16] Roth, C. H., Meyer, B., Frede H. G., Derpsch, R., 1986. The effect of different soybean tillage systems on infiltrability and erosion susceptibility of an Oxisol in Paraná, Brazil. Journal of Agronomy and Crop Science, 157, 217-226.

[17] Muzilli, O., 1983. Influência do sistema de plantio direto, comparado ao convencional, sobre a fertilidade da camada arável do solo. Revista Brasileira de Ciência do Solo, 7, 95-102.

[18] Bell, D. E., Shelman, M., 2006. Monsanto: realizing biotech value in Brazil. Harvard Business School NS-507-218. Boston, Harvard Business School Publishing.

[19] Allard, V., Soussana, J. F., Falcimagne, R., Berbigier, P., Bonnefone, J. M., Ceschia, E., D'Hour, P., Henault, C., Laville, P., Martin, C., Pinares-Pinato, C., 2007. The role of grazing management for the net biome productivity and greenhouse gas budget $(\mathrm{CO} 2, \mathrm{~N} 2 \mathrm{O}$ and $\mathrm{CH} 4)$ of semi-natural grasslands. Agriculture, Ecosystems and Environment, 121, 47-58.

[20] Carvalho, J. L. N., Raucci, G. S., Cerri, C. E. P., Bernoux, M., Feigl, B. J., Wruck, F. J., Cerri, C. C. 2010. Impact of pasture, agriculture and crop-livestock systems on soil $\mathrm{C}$ stocks in Brazil. Soil and Tillage Research, 110, 175-186.

[21] Silva, J. E., Resck, D. V. S., Corazza, E. J., Vivaldi, L., 2004. Carbon storage in clayey oxisol cultivated pasturs in the "Cerrado" region, Brazil. Agriculture Ecosystems and Enviroment, 103, 357-363.

[22] Maia, S. M. F., Ogle, S. M., Cerri, C. C., Cerri, C. E. P. 2010. Changes in soil organic carbon storage under different agricultural management systems in the Southwest Amazon Region of Brazil. Soil \& Tillage Research, 106, 177-184

[23] Soil Survey Staff., 1999. Soil taxonomy: A basic system of soil classification for making and interpreting soil surveys. 2nd edition. Natural Resources Conservation Service. U.S. Department of Agriculture Handbook 436. 
[24] Corazza, E. J.; Silva, J. E.; Resck, D. V. S.; Gomes, A. C. 1999. Comportamento de diferentes sistemas de manejo como fonte e depósito de carbono em relação à vegetação de cerrado. Revista Brasileira de Ciência do Solo, 23, 425-432.

[25] Hulbert, S.H. 1984. Pseudoreplication and the design of ecological field experiments. Ecological Monographs, New York, v. 54, n.2, 187-211.

[26] Blake, G. R., Hartge, K. H., 1986. Bulk density. In: KLUTE, A. (Ed.). Method soil analysis. 2.ed. Madison, ASA, Pt. 1, 364-367 (Agronomy, 9).

[27] Bernoux, M., Cerri, C.C., Cerri, C. E. P., Siqueira Neto, M., Metay, A., Perrin, A.S., Scopel, E., Razafimbelo, T., Blavet, D., Piccolo, M.C., Pavei, M., Milne, E., 2006. Cropping systems, carbon sequestration and erosion in Brazil, a review. Agronomy for Sustaintable Development, 26, 1-8.

[28] Ellert, B. H., Bettany, J. R., 1996. Calculation of organic matter and nutrients stored in soils under contrasting management regimes. Canadian Journal of Soil Science, 75, 529-538.

[29] Moraes, J. F. L., Volkoff, B., Cerri, C. C., Bernoux, M., 1996. Soil properties under Amazon forest and changes due to pasture installation in Rondônia, Brazil. Geoderma, 70, 63-81.

[30] Siqueira Neto, M., Scopel, E., Corbeels, M., Cardoso, A. N., Douzet, J. M., Feller, C., Piccolo, M. C., Cerri, C. C., Bernoux, M., 2010. Soil carbon stocks under no-tillage mulch-based cropping systems in the Brazilian Cerrado: An on-farm synchronic assessment. Soil and Tillage Research, 110, 187-195.

[31] Reichardt, K., 1985. Processos de transferências no sistema solo-planta-atmosfera. 4. ed. Campinas: Fundação Cargill, 466 p.

[32] Franzluebbers, A. J., Stuedemann, J. A., 2010. Surface soil changes during twelve years of pasture management in the southern Piedmont USA. Soil Science Society of American Journal, 74, 2131-2141.

[33] Costa, F. S., Bayer, C., Zanatta, J. A., Mielniczuk, J., 2008. Estoque de carbono orgânico no solo e emissões de dióxido de carbono influenciadas por sistemas de manejo no sul do Brasil. Revista Brasileira de Ciência do Solo, 32, 323-332.

[34] Mendes, F. G., Melloni, E. G. P., Melloni, R., 2006. Aplicação de atributos físicos do solo no estudo da qualidade de áreas impactadas, em Itajubá/MG. Revista Cerne, 12, 211-220.

[35] Colet, M. J., Garbuio, P. W., Delalibera, H. C., Sverzut, C. B., Andrade, J. B., 2008. Produção de silagem da planta inteira de milho conforme manejo do solo na implantação da integração agricultura-pecuária. BioEng, 2, 31-36.

[36] Sisti, C. J., Santos, H. P., Kohhann, R., Alves, B. J. R., Urquiaga, S., Boddey, R. M., 2004. Change in carbon and nitrogen stocks in soil under 13 years of conventional or zero tillage in southern Brazil. Soil and Tillage Research, 76, 39-58.

[37] Whiethölter, S., 2000. Nitrogênio no solo sob plantio direto. Revista Plantio Direto, Jul/Ago, 38-42.

[38] Kichel, A. N., Almeida, R. G., Costa, J. A. A., 2012. Integração lavoura-pecuária-floresta e a sustentabilidade na produção de soja. In: CONGRESSO BRASILEIRO DE SOJA, 6, 2012, Cuiabá, MT. Anais. Cuiabá, MT: Embrapa; Aprosoja, 2012.3p. 1 CD-ROM.
[39] Mendonça, M. M., Urquiaga, S., Reis, V. M., 2006. Variabilidade genotípica de milho para acumulação de nitrogênio e contribuição da fixação biológica de nitrogênio. Pesquisa Agropecuária Brasileira, 41, 1681-1685.

[40] Sommer, R., Ryan, J., Masri, S., Singh, M., Diekmann, J., 2011. Effect of shallow tillage, moldboard plowing, straw management and compost addition on soil organic matter and nitrogen in a dryland barley/wheat-vetch rotation. Soil and Tillage Research, 115-116, 39-46.

[41] Roesch, L. F., Camargo, F., Selbach, P., Sá, E. S., Passagla, L., 2005. Identificação de cultivares de milho eficientes na absorção de nitrogênio e na associação com bactérias diazotróficas. Ciência Rural, 35, 924-927.

[42] Zinn, Y. L., Lal, R., Resck, D. V. S., 2005. Changes in soil organic carbon stocks under agriculture in Brazil. Soil and Tillage Research, 84, 28-40.

[43] Feller, C., Beare, M. H., 1997. Physical control of soil organic matter dynamics in the tropics. Geoderma, 79, 69-116.

[44] Wiseman, C. L. S., Püttmann, W., 2006. Interactions between mineral phases in the preservation of soil organic matter. Geoderma 134, 109-118.

[45] Fisher, M. J., Rao, I. M., Ayarza, M. A., Lascanao, C. E., Sanz, J. I., Thomas, R. J., Vera, R. R., 1994. Carbon storage by introduced deep- rooted grasses in the South American savannas. Nature, 371, 236-238.

[46] Marchão, R. L., Becquer, T., Brunet, D., Balbino, L.C., Vilela, L., Brossard, M. 2009. Carbon and nitrogen stocks in a Brazilian clayey Oxisol: 13-year effects of integrated crop-livestock management systems. Soil \& Tillage Research, $103,442-450$

[47] Conant, R. T., Paustian, K., Elliot, E. J., 2001. Grassland management and conversion into grassland: effect on soil carbon. Ecological Applications, 11, 343-355.

[48] Carvalho, J. L. N., Raucci, G. S., Cerri, C. E. P., Bernoux, M., Feigl, B. J., Wruck, F. J., C. C. Cerri., 2010. Impact of pasture, agriculture and crop-livestock systems on soil C stocks in Brazil. Soil and Tillage Research, 110, 175-186.

[49] D`Andrea, A. F., Silva, M. L. N., Curi, N., Guilherme, R. G., 2004. Estoque de carbono e nitrogênio e formas de nitrogênio mineral em um solo submetido a diferentes sistemas de manejo. Pesquisa Agropecuária Brasileira, 39, 179-186.

[50] Maia, S. M. F., Ogle, S. M., Cerri, C. C., Cerri, C. E. P., 2010. Changes in soil organic carbon storage under different agricultural management systems in the Southwest Amazon Region of Brazil. Soil \& Tillage Research, 106, 177-184.

[51] Maia, S. M. F., Ogle, S. M., Cerri, C. E. P., Cerri, C. C., 2009. Effect of grassland management on soil carbon sequestration in Rondônia and Mato Grosso States, Brazil. Geoderma, 149, 84-91.

[52] Corazza, E. J.; Silva, J. E.; Resck, D. V. S.; Gomes, A. C. 1999. Comportamento de diferentes sistemas de manejo como fonte e depósito de carbono em relação à vegetação de cerrado. Revista Brasileira de Ciência do Solo, 23, 425-432.

[53] Marchão, R. L., Becquer, T., Brunet, D., Balbino, L.C., Vilela, L., Brossard, M. 2009. Carbon and nitrogen stocks in a Brazilian clayey Oxisol: 13-year effects of integrated crop-livestock management systems. Soil \& Tillage Research, $103,442-450$. 
[54] Siqueira Neto, M., Scopel, E., Corbeels, M., Cardoso, A. N., Douzet, J. M., Feller, C., Piccolo, M. C., Cerri, C. C., Bernoux, M., 2010. Soil carbon stocks under no-tillage mulch-based cropping systems in the Brazilian Cerrado: An on-farm synchronic assessment. Soil and Tillage Research, 110, 187-195. 